Trinity University

Digital Commons @ Trinity

Modern Languages and Literatures Faculty

Research

Modern Languages and Literatures Department

Summer 1984

\title{
Some Practical Thoughts on Producing Calderón’s Court Plays
}

Matthew D. Stroud

Trinity University, mstroud@trinity.edu

Follow this and additional works at: https://digitalcommons.trinity.edu/mll_faculty

Part of the Modern Languages Commons

\section{Repository Citation}

Stroud, M.D. (1984). Some practical thoughts on producing Calderón's court plays. Bulletin of the Comediantes, 361, 33-41. doi:10.1353/boc.1984.0016

This Article is brought to you for free and open access by the Modern Languages and Literatures Department at Digital Commons @ Trinity. It has been accepted for inclusion in Modern Languages and Literatures Faculty Research by an authorized administrator of Digital Commons @ Trinity. For more information, please contact jcostanz@trinity.edu. 


\section{SOME PRACTICAL \\ THOUGHTS ON PRODUCING \\ CALDERÓN'S COURT PLAYS}

MATTHEW D. STROUD
Trinity University

There are two approaches to the production of Spanish Golden Age plays. One can create a new theatrical work that allows the creative personnel to stage their own concept, or one can try to recreate the historical event, in which case authenticity becomes an important consideration. Authenticity, however, is a relative term, especially when applied to seventeenth-century court plays, those musical and mythological extravaganzas presented to Philip IV and Charles II. Lyric theater is one of the most complicated and expensive genres of stage production to begin with, and the problems are compounded when one deals with a group of plays practically unknown to opera and theater people, musicologists, and audiences. To produce Golden Age court plays in the United States, one must contend with the lack of any recent versions to which to tum for answers and advice, few competent singers with the capability to manage a Spanish text, and, in general, a lack of interest on the part of most people other than scholars. One must convince directors, musicologists, singers, and funding institutions of the validity of spending so much time and money on a work that no one has ever seen and few have ever heard of, and that doesn't even have any arias as we have come to expect them. The major appeal of such a production is clearly not to a mass audience; instead it must appeal to those individuals and institutions that see the value in restaging early dramatic 
works and whose income is not dependent on box office sales. Quite often for these institutions, notably universities and production companies funded in large part by public and private grants, it is precisely the historical value of a work that provides the principal motivation for production. The importance of history necessarily leads to discussions of authenticity. In this brief overview, I should like to address problems that one faces in producing Golden Age court plays in a more-or-less authen. tic fashion, especially with regard to staging, text, and music, with occasional references to the problems encountered with Trinity University's 1981 production of Celos aun del aire matan. Our small-scale production is by no means a perfect model, but it is one that has been produced and has raised pragmatic questions, the answers to which could be reduced in many cases to hours of manual labor and hard-dollar expenditure.

It is an unfortunate reality that the quality of an authentic recreation is almost wholly a function of the money available. Using university resources (which means no rental fee for the hall, student labor, student singers, student instrumentalists and faculty members as musical director, vocal coach, and producer), we spent over $\$ 10,000$, primarily on costumes, sets, and modest stipends for the stage director, lighting director, and set designer.' It would have been very easy to spend more than $\$ 100,000$ and still not have achieved a completely authentic production. I suppose that, with enough money, one could reconstruct the Coliseo of the Palacio del Buen Retiro, installing footlights and stage machinery, and reproduce the production schedule much as we imagine they did in 1660. Even then, of course, we could never bring back Philip IV and Mariana of Austria or the various political reasons for the presentations of the spectacles in the first place. Thus, starting from the in escapable fact that no modem production can ever be absolutely authentic, one must content oneself with a few basics, adding as many special effects as the budget and the skill of the personnel will allow.

Actually, there is quite a bit of data conceming the staging of the court plays, including three sets of complete drawings of the scenery." The basic Itallanate wing and shutter perspective design is not difficult to set in place, and any minimally authentic production should produce it. Scene changes are more difficult, but again not outrageously so. It is in the area of stage machinery that major compromise begins. We know that court theaters all over Europe employed massive machinery con sisting primarily of ropes and pulleys in order to stage special effects." Consider the following stage direction as one example:
Aura appears in the air in a cart drawn by two chameleons, and, singing, she descends to the stage, passing in front of everyone without their seeing her, and she ascends again on the other side with the last line."

Let us assume for the moment that the directions are authentic even though the stage directions come only from printed versions rather than the manuscript. If the stage has the capacity to fly the actress, so much the better. Not all stages, however, have the necessary hardware to reproduce the more impressive effects in this and other examples: giant rocks that open to reveal palace gardens, ' Galatea rising out of the sea, Cupid and Anteros seated on thrones floating on clouds.' After all, these plays are known for their spectacular effects based primarily on rapid scene changes (mutaciones) and discoveries (apariencias). Modem technology can help solve some of the logistical problems, either by the use of motors to drive the machines or, more importantly, by the use of lighting. The original stage designers had no electricity and, therefore, no capacity for lighting effects as we know them, although they did make use of chiaroscuro effects in painting the scenery. Part of the reason for the elaborate machinery was to produce special effects the best way they could. Today we can use any number of unhistoric but very effective means for producing special lighting effects: blackouts, color washes, transparency projections, spotlights, and so on. When the medium is film or videotape, the possibilities for special effects are practically endless. Though unauthentic in their execution, these effects do respond to the reason for the original machine effects-to add more visual stimulation for the audience. It is considerably easier to be faithful to the spirit of the text than to the details of the original production.

Costumes and hair styles of the period would have reflected those of the court. ' Considering the wealth of extant paintings of members of the court of Philip IV, it is not difficult for the costumer to get a rather accurate idea of the fashions at court thoughout the seventeenth century, although detail in the workmanship is often difficult to discem. The practical problems of the costumer relate to how omate one wants the costumes to be, color and design according to character status and personality, the desirability of using hip-rolls or farthingales over the more authentic hoop skirts.' Hair styles are somewhat more problematical, in part because of the usually impressionistic treatment of hair by Veláz. quez and others, and partly because very few portraits show the backs of heads. "In fact, both costumes and hair styles represent the greatest 
number of decisions that must be made about details. At some point, someone must decide how many buttons are on a shirt, what shoes the characters should wear, where the hair is parted, and so forth.

Acting styles of the period would be considered quite excessive by today's standards. Jack Sage has docurnented to some degroe the style of acting most appreciated in the Baroque: overwrought emotions, development of character only within the limits of certain efigures» or types, and the attempt to fill the spectator with awe and imagination. ${ }^{\prime \prime}$ Such histrionics are today seen only in parodies of melodrama, and some compromise needs to be made between the larger-than-life characters of the plays and the current desire to find real human motivation in the actions of the people on stage. Again, such decisions are a matter of taste and must be dealt with by producer, director, and actors early in the production process.

The text poses two principal problems. The first of these involves cuts. While to a literary scholar the idea of cutting text is unspeakable heresy, there are nevertheless compelling reasons for wishing to do so. In fact, if one eliminates the loas and the entremeses, most of which do not accompany the texts of the major plays with which they were originally performed, one has already made cuts. Futhermore, the music of the era was strophic in nature, and in the Baroque, the repetitions of verses became longer and longer as the seventeenth century progressed. In Celos, for example, the gracioso at one point repeats the same melodic line forty-two times (I, 387-428); on another occasion, Diana and the Furies sing nineteen verses of the same tune (III, 1433-1508). Perhaps productions should include all the strophic variations so that we might more fully appreciate the weight of Baroque repetition than we can do by hearing only two or three stanzas at a time. One cannot help but think that a modem audience would grow restless after so many repetitions of the same tune, no matter how catchy it may be. Moreover, cutting strophic variations also allows a cut in performance time. The three act Celos has two acts of approximately fifty minutes each and a final act of one hour and fifteen minutes. That is about the same running time as Don Giovanni, but the music is much more repetitive. There is, in fact, no true aria in the entire opera. The compromise here is one betwoen rigorously following the complete text and trying to lighten some of the historical weight from a production that will most likely be the audience's introduction to Golden Age court plays if not Golden Age drama in general. It is a hard decision, and each production must come to its own solution."
The second major problem with the text is one that has perennially confronted editors of the plays: which version is better, and which version is more authentic? This problem is espocially true of the plays that do not have an autograph manuscript version. It is to be hoped that, if one is able to arrive at definite answers at all, the better version and the more authentic version will be the same one. The choice is often com. plicated when the music is considerad as well as the text. One particular example from Celos is a line by Eróstrato: *...me tiene con recelo / de si fui visto o no,» to which Rústico says, «iVálgame el cielo!» (I, 373-74). The lines rhyme (recelo, cielo) and scan well as part of the silva. Unfortunately, the music goes with an alternate version found in the manuscript: *me tiene el corazón rezeloso / de si fue visto o no,n which not only neither rhymes nor scans, but which suffers poetically as well. For performance we chose the latter version, the only change being afui for kfuew; for publication, we chose the former.

The musical component of these plays is the area in which one is least sure of the truth and has to depend on educated guesses. The reason, naturally enough, is that there is less music of the era to study than either literary texts or treatises on staging. Indeed, there are very few works for which we have all the music available, ${ }^{\prime \prime}$ although certain others could be produced through skillful reconstruction." Tessitura, pitch, and instrumentation / orchestration all pose problems. As is well known, most of the roles in the court plays were performed by women. ${ }^{15}$ Consequently, one must either cast women in those roles written for sopranos, or transpose the male roles for tenors and basses. Transposition involves its own problems, however. Because there are no separate arias, to transpose one part automatically implies transposing an entire section in most cases. Moreover, pitch itself is a relative concept until the nineteenth century, and there has long boen a debate over whether earlier manuscript notation represents a pitch higher than, lower than, or the same as that of today. Some eminent musicologists believe that Spanish music of the time was written a fourth or a fifth higher than it sounded. ${ }^{16}$ Others of equal stature present evidence to the effect that Baroque notation may have varied over the years, but that it did not vary all that much." With that debate as background, the musicologist working on a specific production must also take into consideration the capability and ranges of the singers in that production. In Celos, for example, the role of Aura is particularly high, perhaps because of its dramatic content and because the character does, after all, represent air. Lowering Aura's part involves problems with other characters that are 
already at the lower end of their ranges. ${ }^{18}$ Futhermore, these decisions need to be made before any of the expensive and time-consuming process of copying parts begins, because it is not as easy for instumentalists to transpose while playing as it is for vocalists to transpose while singing.

Then there is the matter of instrumentation and orchestration. Not one of the existing musical accompaniments for the theater contains more than a voz y bajo (melodic line and simple indication of basso continuo), from which the musicologist must recreate the full partitura in cluding the figured bass. Instrumentation is very important in the strophic variations where the primary musical interest comes from the use of different instruments in the repetitions. We do know the instruments in the royal chapel orchestra in $1633,{ }^{\prime \prime}$ 'but all such information tells us is that combinations of strings and winds were used. There is no indication that certain instruments were used in particular plays, or the specific manner in which they were combined to produce different timbres. In addition, to be faithfully authentic, chirimias and bajoncillos should be located and used rather than other instruments, usually from northem Europe or Italy, normally found in Collegia Musica. Even if one were to go to the trouble of obtaining reproductions of the Spanish in struments, there is no guarantee that the modern construction would produce the exact timbre and pitch of the original ones

In summary, a truly authentic production of a Spanish Golden Age court play is impossible. We do not know the pitch, the instrumentation the exact text used, the exact scenery for most plays, or which loas and entremeses accompanied the majority of the comedias de tramoyas. Moreover, there are legitimate reasons to alter authenticity even when it is possible: the use of the electricity, the use of men in male roles, modem acting techniques, cuts to reduce playing time and repetition, and the like. What one soeks in such a recreation, then, is not adherence to every detail of the historical original, but an attempt to recreate the effect of the original-its basic overall appearance, its grandeur, its spectacle, its entertainment. In large part, the role of the modem producer is the same as that of the original producer. One must take the poet's words and the composer's music, create a dramatic environment in which the action can take place given the limitations of budget, personnel, and the theater in which the play is to be presented, and somehow make the end product entertaining to an audience. It is comforting to know that our efforts are still well rewarded, for these works continue to offer interesting actions, engaging melodies, and amusinggraciosos. The
Spanish Golden Age court plays may not be up to the standards of Verdi and Mozart, or even Handel and Lully, but they do not deserve the neglect that they have suffered for the past two centuries.

NOTES

1. The outside funding for Celos oun del aire matan was provlded by a grant from the Ewing Halsell Foundatlon of San Antonlo.

2. The illustrations for Calderris's La fiesa, el rayo y ka piedra were tirst published by Angel Valbuena Prat, ala escenografta de una comedla de Calderón, AEAA, 6 (1930), 1-16, and they have been reproduced several tlmes. The illustratlons for Juan Vélez de Guevara's Los celos hocen estrellas can be found in the editlon of that work by John E. Varey and N. D. Shergoidd (London: Tómesls, 1970). Eleven drawlngs for Fortunas de Andiómeda y Perseo are offered by Phyllis Dearbom Massar, «Scenes for a Calderón Play by Bacclo del Blanco,- Master Drawings, 15 (1977), 365-75 and plates 21-31. Ground plans of the Coliseo of the Buen Rettro are reproduced in N. D. Shergold, A History of the Sponish Stoge (Oxtord: Clarendon Press, 1967), plates 3, 29, and 30. Ground plans of the Solon dorado of the Alcaszar are reproduced in the Varey.Shergold edition of Los celos hocen estrellos mentloned above, plate 13. For more Information on sources relatlve to staging, costurning, etc., for the Golden Age theater, the two most important references are Hugo A. Rennert, The Sponish Stage in the Time of Lope de Vega (New York: Hispanlc Soclety of America, 1909; rpt. New York: Dover, 1963), and Shergold's History, both of which provide coplous references to historical documents. For a further blbliography on the history of the Spanish lyric theater, see my edition of Calderon's Celos aun del aire maton, (San Antonlo: Trnlty Unlv. Press, 1981), which !s also the source of all referenoes to Celos in this article.

3. For a comparison wlth staging technlques in other countries, see Bamard Hewltt, ed., The Renoissance Stoge: Documents of Sertio, Sobbattini, and Furttenbach, trans. Allardyce Nicoll, John H. MeDowel, and Georye R. Kemodle (Coral Gables: Unlv. of Mlaml Press, 1958); Stephen Orgel and Roy Strong, Migo Jones: The Theatre of the Stuart Court. 2 vols. (Berkeley: Unlv. of Calltornla Press, 1973); and Percy Simpson and C. F. Bell, Designs by Inigo Jones for Masques and Plays at Court (New York: Russell and Russell, 1924; rpt. 1966)

4. Celos aun del aire maton, p. 112.

5. Celos aun del aire maton, p. 146.

6. Pedro Calderón de la Barea, El mayor enconto amor, in Obras completos, ed. Angel Valbuena Briones (Madrld: Aguilar, 1959), I, 1544.

7. Calderón, La fiera, el rayo y lo piedra, in Obros completos, I, 1630. 
8. Reınert, p. 104.

9. Such details were pointed out to me by the costumer of Celos aun del aire maton. John 11юmas Davis of San Antonlo.

10. Hair styles are generally given only secondary consideration in treatises on costum. Ing. Such a basic work as Blanche Payne's History of Costume (New York: Harper and Row, 1965), pp. 357, 361.62, 372.73, 382, has only six paragraphs relating to hairstyles in the entre seventeenth certury throughout Europe, and nowhere does she Indlcate how such hairstyles were achieved. Velszquez is, as with costunes, a source authority for hair styles, but only a few paintings show women from the side or the back llas Meninas, Las Hillanderas. Sibila, La Venus del Espefo). Pardoularly unfortunste in the Trinity production of Celos was the inattention to the hairstyles of the male character Céfalo. The actor who played that role was in the Atr Force and his halr was intolerably short, despite constant pleas from the costuner.

11. Jack Sage, «Texto y realizaclón de Lo estatur de Prometeo y otros dramas musicales de Calderón,s in Hacia Colderon. Coloqulo anglogemmono, ed. Hans Flasche (Berlln: Walter de Gruyter, 1970), pp. 39.40. The director of the Tilnity production, Robert Baca of the Unlversity of Utah, chose a modern approach to direction rather than an atternpt to recreate Baroque histionics. He relied on small gesture and facial expression rather than broad movennent, and, due to the intlmate nature of the theater, the actors were able to communicate with the audience quite well. Of course, Baca was also limited in his dinecton by the fact that the students were selected for their musical abulity rather than their acting ability.

12. With respect to the Trinity production of Celos, two additional constralnts forced more cuts. The finding institution wanted the production to consist of three acts of ap. proximately thitty minutes each. Moreover, some of the more immature members of the student cast did not leam their parts in tlme and, as a result, cuts had to be made. It should be noted that cutting is an art in Itself. Because the action of Celos is so complex and tightly constructed, it was very difflcult to cut whole soenes. Thenefore, cuts generally took the form of one or two repetitlons of strophlc variatlons at a time, or a bit of recitatlve dlalogue here and there. In some cases, only a word or two was cut from a line of poety; the result made sense but it lacked both rhyme and meter. In one instance (III, 1863), a cut was in. advertently made during rehearsal without consultation. The result was a wholly ungram. matical usage because voz was substtuted for nombre wlthout changing the gender of the accompanying article and adjective.

13. Based primarly on the works of Pedrell, José Subirs, Masicos al serviclo de Calderón y de Comella," Anuorio Musical, 22 (1967), 19-205, and Jack Sage, .La música de Juan Hidalgo, in the Varey.Shergold editton of Los celas hacen estrellas, pp. 183-223, discuss some of the extant music. The most serious study of existing music of the Spanish Baroque is that currentiy being underaken by Loulse K. Stetn, whose results will no doubt constitute a major contribution to the held.
14. Jack Sage, for example, was Inttially involved in the planning of Celos because the origlnal Idea, concelved by Alexander A. Parker and sponsored in San Antonlo by Mrs. Mary Ann Brunl of Festlval Calderón, Inc., was to produce a verslon of Calderón's El divino Orfoo using his reconstuuction of a musical score that no longer exists.

15. Robert Stevenson, Estudio preliminar, in his edition of La parpura de la rosa, by Pedro Calderón de la Barca and Tomás de Torrejón y Velasco (LIma: Instituto Nacional de Cultura, Biblioteca Nacional, 1976), pp. 28-29; and José Sublir, „Calderón de la Barca, llbrettsta de Gpera: Consideractones ilterario-musicales, $\approx$ Anwario Musicol, 20 (1965), 61.

16. Stevenson, pp. 65.66, states that it was a usual practice of vihuela music.

17. Robert Donington, The Interpretation of Early Music, new verslon (London: Faber and Faber, 1974), pp. 511.12, believes that in general there is no particular reason to interpret early music at a pitch other than $a^{\prime}=490$. Gerald R. Benjamin, the musloologist who transcribed the performing edition of Celos oun del aire matan agrees, while admittling that a varation of as much as a fill step is possible. It seems that the discrepancy may reside in the difference in the notation of uthuela muslc as opposed to harp music (Juan Hidalgo was a harpist). Unfortunately for those interested in studying Benjamin's Impressive score, the manuscript remains unpublished.

18. Prindpally Cefalo. As one might expect, the only part completely comfor table for a male voice is that written for a man, the role of Rustloo.

19. .... dos bajones, un bajoncillo, tres arpistas..., dos músicos de viliuela y otros dos de violón, más chirimías y cometas; y transcurvidos un par de anos se agregaban a dicha car poraclón fllarmónica slete viollnes." José Sublrá, «Prólogon to Celos aun del aire matan: Opera del siglo XVII. Texto de Calderón y masica de Jwan Hidalgo (Barcelona: Institut d'Estudls Catalans, Biblioteca de Catalunya, 1933), pp. xilil-xiv. 